\title{
Determination of the Water Quality Index (NFS WQI) of water bodies in the Huasteca Potosina, Mexico
}

Hilda Guadalupe Cisneros Ontiveros ${ }^{1}$, Nahum Andres Medellín Castillo ${ }^{1,2}$, Abraham Cárdenas Tristán ${ }^{1}$, Marisol Castro Cárdenas ${ }^{1}$, César Arturo Ilizaliturri Hernández², Ratih Fitria Putri ${ }^{3 *}$

${ }^{1}$ Faculty of Engineering, Autonomous University of San Luis Potosi, San Luis Potosi 78290, Mexico

${ }^{2}$ Multidisciplinary Graduate Program in Environmental Sciences, Autonomous University of San Luis Potosi, San Luis Potosi 78210, Mexico.

${ }^{3}$ Department of Environmental Geography, Faculty of Geography, Universitas Gadjah Mada, Indonesia

\begin{abstract}
The water quality of water bodies in Huasteca Potosina was assessed by the National Sanitation Foundation Water Quality Index (NFS WQI) depending on nine water quality parameters include physical, chemical, and biological properties. The water quality obtained at the sampling site 50-90 in the NSF-WQI range shows the medium quality. Results revealed that the Moctezuma River in Tanquian de Escobedo has low water quality with a score of 50, the Tancuilin and Axtla Rivers have good water quality, and the Moctezuma River (Tampamolón Corona), Amajac River, Valles River, Panuco River, Patitos Lagoon, Plan de Iguala Lagoon were all located in medium water quality. This indicates that the water quality of the Huasteca Potosina is irregular, due to the presence of contaminating agents coming from fertilizers, pesticides, domestic water, and residual water from the communities adjacent to the rivers and lagoons, causing an environmental impact to the aquatic ecosystems of the place. However, this research shows the importance of making use of the water quality index in this region, this to relate the environmental impacts responsible for the contamination of surface water and interpret the experimental data of this water quality monitoring to facilitate decision making and consider frequent monitoring of the quality of water bodies in the Huasteca Potosina.
\end{abstract}

\section{Introduction}

The state of San Luis Potosi, Mexico, is divided into four zones: Altiplano, Centre, Media, and Huasteca. The study zone for this work focused on the Huasteca, which is east of the state. Figure 1 shows the zones, where the green shaded area represents the study zone. The Huasteca Potosina, which includes 19 of the 58 municipalities in San Luis Potosi state, has an area of approximately $12,500 \mathrm{~km} 2$ and represents $17.3 \%$ of the total state surface [1].

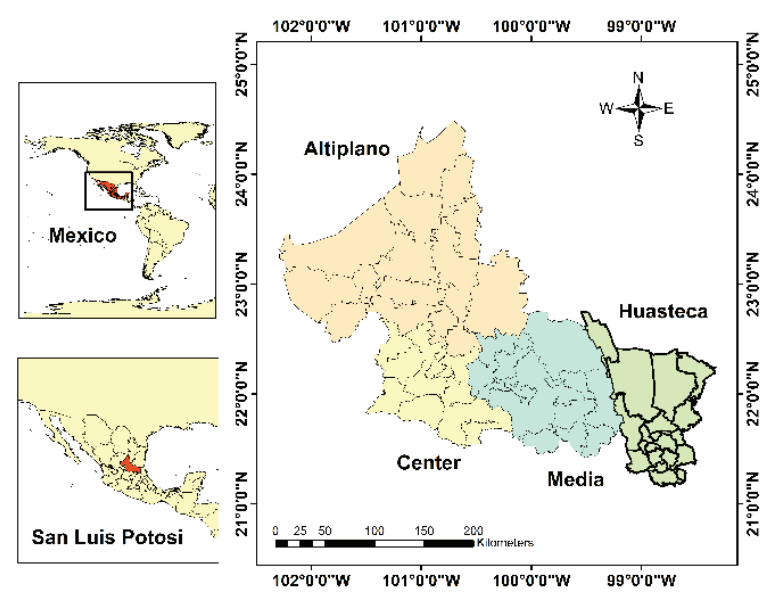

Fig.1. Huasteca Potosina
The Huasteca Potosina is in the hydrological region Panuco No. 26, according to the classification of CONAGUA. This area is divided into two portions: Upper and Lower Panuco. The Huasteca is in the lower portion, where a good number of runoffs are generated, tributaries that, in some way, are of great importance for the Panuco River. This river originates in the State of Mexico, enters the Sierra Madre Oriental on a rugged topography, which is more notable as the current descends, until the confluence of the Tempoal and Tampaón rivers. It receives the name of the river Panuco and continues with that designation until its mouth in the Gulf of Mexico, downstream from Tampico, Tamaulipas [2]. Its relief is slightly undulating with altitudes that oscillate approximately between 50 and 3000 meters above sea level. The hydrological region No. 26 is subdivided by four basins: Panuco River, R. Tamuin, R. Tamesi, and R. Moctezuma. The sub-basins that comprise the Huasteca Potosina are R. Panuco, R. Tamesi, Río Tampaon, R. Valles, R. Puerco, R. Mesillas, R. de Los Naranjos, R. Gallinas, R. Moctezuma, R. Axtla, R. Amajac, and R. San Pedro.

The Water Quality Index (WQI) became evolved in 1970 through the National Sanitation Foundation (NSF) of the United States, using Rand Corporation's Delphi research technique [3]. The WQI was formulated by the NFS as a quantitative aggregation of diverse selected

\footnotetext{
* Corresponding author : ratihfitria.putri@ugm.ac.id
} 
and weighted water exceptional parameters to symbolize the excellent expert judgment of 142 professional respondents into one index [4]. Using a weight factor to distinguish the importance (weightinferred and determined by experts) of every parameter for the future result is one of quantitative method with mathematical equations.

The INSF has the characteristic of being a multiparameter index and is based on three studies. In the first one, 35 contamination variables included in the index were tested; the experts gave their opinion about them and classified them in three categories according to the parameter should be: "not included," "undecided," or "included." Among those included, they had to give a score from 1 to 5 , according to their greater or lesser importance, with one being the most significant. They also had the opportunity to include more variables. In a second study, all the experts' answers were compared, so that the answers could be modified if deemed appropriate. As a result of this second study, nine identified variables of significant importance were identified: Fecal Coliforms, Dissolved Oxygen, $\mathrm{pH}$, Temperature, $\mathrm{BOD}_{5}$, Phosphates, Nitrates, Deviation, Total Solids, and Turbidity.

Finally, in the third study, participants were asked about developing an assessment curve for each variable. Water quality levels ranged from 0 to 100 , located on the ordinates and the different levels of the variables on the abscissae. Each participant made the curve they thought represented the variation in water quality caused by the variables' level of contamination. These curves were known as "Functional Relations" or "Function Curves" [6-7].This study aims to evaluate the water quality status of water bodies of Huasteca Potosina based on NSF-WQI.

\section{Method}

\subsection{The study area}

Table 1 shows the water bodies for which the INSF was determined.

Table 1. Geographic location of the sites sampled in the

\begin{tabular}{|c|c|c|c|c|}
\hline & \multirow{2}{*}{ Municipality } & \multirow{2}{*}{ Water body } & \multicolumn{2}{|c|}{ Geographical coordinates } \\
\hline & & & Latitude & Longitude \\
\hline S1 & Tamazunchale & Amajac River & $21^{\circ} 14^{\prime} 46^{\prime \prime}$ & $98^{\circ} 46^{\prime} 33^{\prime \prime}$ \\
\hline $\mathrm{S} 2$ & Matlapa & $\begin{array}{c}\text { Tancuilín } \\
\text { River }\end{array}$ & $21^{\circ} 21^{\prime} 25.3^{\prime \prime}$ & $98^{\circ} 51^{\prime} 51^{\prime \prime}$ \\
\hline $\mathrm{S} 3$ & Axtla de Terrazas & Axtla River & $21^{\circ} 26^{\prime} 02^{\prime \prime}$ & $98^{\circ} 52^{\prime} 39^{\prime \prime}$ \\
\hline S4 & Axtla de Terrazas & $\begin{array}{l}\text { Moctezuma } \\
\text { River }\end{array}$ & $21^{\circ} 25^{\prime} 55^{\prime \prime}$ & $98^{\circ} 49^{\prime} 46^{\prime \prime}$ \\
\hline S5 & $\begin{array}{c}\text { Tampamolon } \\
\text { Corona }\end{array}$ & $\begin{array}{l}\text { Moctezuma } \\
\text { and Claro } \\
\text { Rivers }\end{array}$ & $21^{\circ} 29^{\prime} 28^{\prime \prime}$ & $98^{\circ} 47^{\prime} 51^{\prime \prime}$ \\
\hline S6 & $\begin{array}{l}\text { Tanquian de } \\
\text { Escobedo }\end{array}$ & $\begin{array}{l}\text { Moctezuma } \\
\text { River }\end{array}$ & $21^{\circ} 35^{\prime} 32^{\prime \prime}$ & $98^{\circ} 39^{\prime} 22^{\prime \prime}$ \\
\hline S7 & Tamuin & $\begin{array}{l}\text { Patitos } \\
\text { Lagoon }\end{array}$ & $22^{\circ} 2^{\prime} 30.7^{\prime \prime}$ & $98^{\circ} 46^{\prime} 17^{\prime \prime}$ \\
\hline S8 & Tamuin & $\begin{array}{l}\text { Tampaon } \\
\text { River }\end{array}$ & $22^{\circ} 00^{\prime} 04^{\prime \prime}$ & $98^{\circ} 46^{\prime} 25.27^{\prime \prime}$ \\
\hline S9 & Ebano & $\begin{array}{c}\text { Plan de Iguala } \\
\text { Lagoon }\end{array}$ & $22^{\circ} 02^{\prime} 16^{\prime \prime}$ & $98^{\circ} 27^{\prime} 28^{\prime \prime}$ \\
\hline $\mathrm{S} 10$ & Veracruz & Panuco River & $22^{\circ} 02^{\prime} 12^{\prime \prime}$ & $98^{\circ} 24^{\prime} 0^{\prime \prime}$ \\
\hline S11 & Cd. Valles & Valles River & $21^{\circ} 59^{\prime} 12^{\prime \prime}$ & $99^{\circ} 01^{\prime} 15^{\prime \prime}$ \\
\hline S12 & Tamasopo & $\begin{array}{l}\text { Puente de } \\
\text { Dios River }\end{array}$ & $21^{\circ} 55^{\prime} 48^{\prime \prime}$ & $99^{\circ} 24^{\prime} 59^{\prime \prime}$ \\
\hline
\end{tabular}

\subsection{Water samples collection and analysis}

Water samples were taken at the sites corresponding to the map in Figure 2 in the period of August 2019, 1.5 L of the sample were taken with sterile polyethylene containers, stored at $4^{\circ} \mathrm{C}$ for later transport until analysis. At the sampling time, the bottles were rinsed three times with the river or lake water before the final sample was taken (see Figure 3).

The physicochemical and microbiological parameters evaluated for each water body were fecal coliform (FC), dissolved oxygen (DO), $\mathrm{pH}$, temperature (T), biochemical oxygen demand (BOD), phosphates $\left(\mathrm{PO}_{4}\right)$, nitrates $\left(\mathrm{NO}_{3}\right)$, total solids (TS), and total turbidity (Tur.). The parameters measured in situ were carried out with the help of a multiparametric probe.

The parameters analyzed ex-situ were carried out in the Environmental Chemistry Laboratory of the Faculty of Chemical Sciences UASLP.
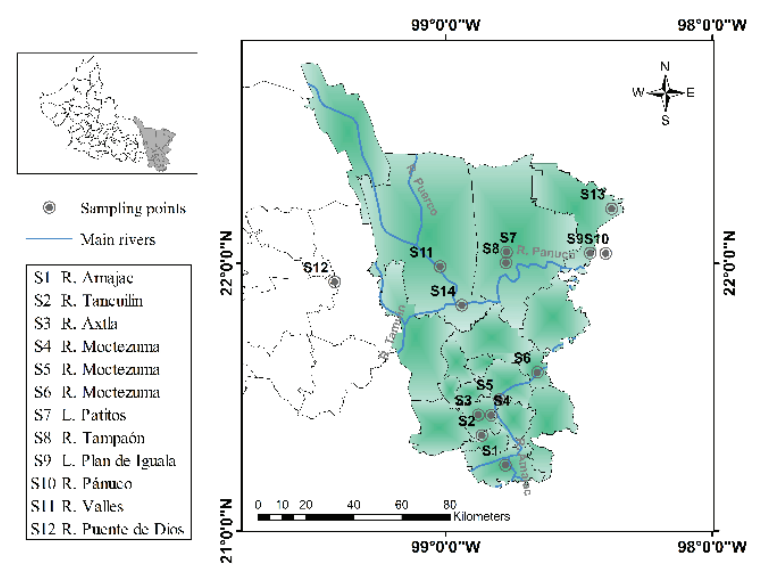

Fig.2. Geographic location of sampling points in Huasteca Potosina

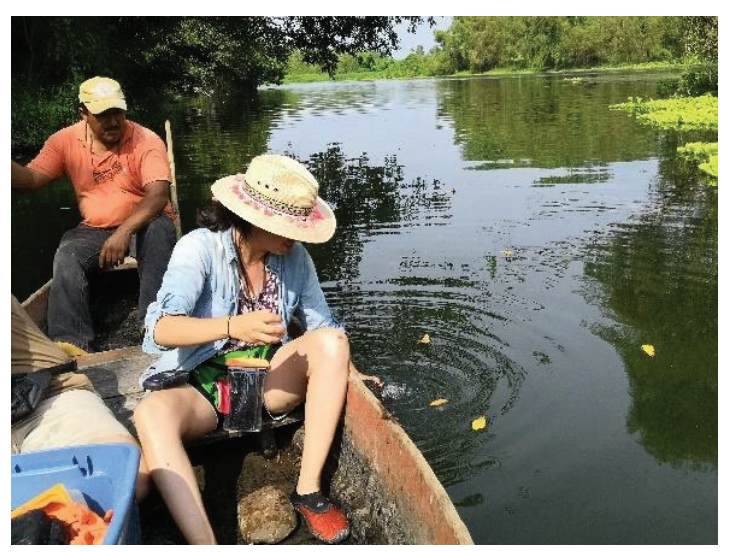

Fig.3. Water sampling in the Moctezuma River

\subsection{The national sanitation foundation's water quality index (NSF-WQI)}

The index developed by [7-9] is on a 100-point scale representing the results of nine variables, such as BOD, DO, NO3, PO4, T, Tur., TS, pH, and FC. The index calculator is to be had online: http://www.waterresearch.net/index.php/water-treatment/water monitoring/monitoring-the-quality-of-surfacewaters [10]. 
This index represents water quality in general and does not look at water use capacities. Several index parameters have exclusive importance, so a weighted average is beneficial for calculating the index, Table 2 . The temperature extrade refers back to the temperature di between upstream and downstream control sites [8, $11]$.

Table 2. Weight scores of the nine NSF-WQI parameters

\begin{tabular}{cc}
\hline Parameters & Weighted mean \\
\hline $\mathrm{DO}, \mathrm{mg} / \mathrm{L}$ & 0.17 \\
$\mathrm{FC}, \mathrm{CFU} / 100 \mathrm{~mL}$ & 0.16 \\
$\mathrm{pH}$ & 0.11 \\
$\mathrm{BOD}, \mathrm{mg} / \mathrm{L}$ & 0.11 \\
$\mathrm{~T},{ }^{\circ} \mathrm{C}$ & 0.1 \\
$\mathrm{NO}_{3}, \mathrm{mg} / \mathrm{L}$ & 0.1 \\
$\mathrm{PO} 4, \mathrm{mg} / \mathrm{L}$ & 0.1 \\
$\mathrm{Tur} ., \mathrm{NTU}$ & 0.08 \\
$\mathrm{TS}, \mathrm{mg} / \mathrm{L}$ & 0.07 \\
\hline
\end{tabular}

The weighted score (Wi) should be expanded with the aid of using the subindex value (SI) of the parameter acquired with the aid of using the NSFWQI; then it is going to be summed with the index equation [8].

$$
N S F W Q I=\sum_{i=1}^{n} S I_{i} W_{i}
$$

where NSF-WQI is the score of the water quality index; $\mathrm{SI}$ is the sub-index value, and $\mathrm{Wi}$ is the weighted score (all calculated through the index calculator to be had online).

The wide variety received from making use of the index is classed in 5 scale classes as in Table $3[7,12]$.

Table 3. NSF-WQI categories

\begin{tabular}{cc}
\hline Range & Quality \\
\hline $0-25$ & Very bad \\
$26-50$ & Bad \\
$51-70$ & Medium \\
$71-90$ & Good \\
$91-100$ & Excellent \\
\hline
\end{tabular}

\section{Results and discussions}

\subsection{Water quality parameters}

The World Health Organization (WHO) (2011) water consumption standards [13] to compare with the quality data of the Huasteca Potosina water bodies, which presented in Table 4.

The $\mathrm{pH}$ scale used quantifies the alkalinity and acidity of the water. The $\mathrm{pH}$ range in this study was 7.68.8. The Huasteca water bodies' $\mathrm{pH}$ levels tend to be alkaline because there are naturally occurring carbonates and bicarbonates in solution, typical of karst systems in the geomorphology of the study area.

DO is important to aquatic existence for respiration, and most organisms have a really perfect scope of DO. Results for DO concentrations in water bodies were 4.7 to $10.5 \mathrm{mg} / \mathrm{L}$, and saturation percentages ranged from
61.6 to $142.2 \%$. Water bodies with concentrations greater than $5 \mathrm{mg} / \mathrm{L}$ indicate sufficient oxygen for most aquatic organisms. High levels of DO are conducive to improved water quality.

Temperature can determine the charge of biochemical responses withinside the aquatic ecosystem [14]. The water temperature range is $25-33.4{ }^{\circ} \mathrm{C}$; the variation with the ambient temperature was about $9^{\circ} \mathrm{C}$.

Turbidity is a degree of the clarity of water. Turbid water reduce light infiltration and impacts photosynthesis and aquatic life. High total solids can enhance the temperature of the water temperature because stable substances get warmness from daylight [15]. The minimum value of turbidity was in the $\mathrm{R}$. Puente de Dios with a value of 0.2 NTU; on the contrary, the maximum value of turbidity was in Patitos lagoon with a 190 NTU value. TS levels varied from 154 to $2006 \mathrm{mg} / \mathrm{L}$.

BOD is the amount of oxygen used by bacteria and fungi to decompose organic compounds in water for five days [16]. In the Huasteca water bodies, the BOD levels were from 0 to $8.0 \mathrm{mg} / \mathrm{L}$; this indicates that the higher the BOD concentration, the lower the DO content, causing damage to aquatic organisms. Water bodies with BOD concentrations lower than $3 \mathrm{mg} / \mathrm{L}$ favor water quality [17].

For plants and aquatic creatures, nitrate is an important supplement to be able to use nitrogen. Soil erosion, agricultural waste to domestic waste, is a source of nitrate [18]. Nitrate concentrations in Huasteca water bodies are relatively low according to WHO criteria [13], because the ranges varied from 0.3 to $19.6 \mathrm{mg} / \mathrm{L}$.

Another important supplement for plants and creatures in their growth is phosphate. However, a high concentration of phosphate in water is also not good because it can increase eutrophication. Phosphate can come from detergents, fertilizers and waste [19]. The concentration of phosphates in the Huasteca water bodies 0.2 to $8.9 \mathrm{mg} / \mathrm{L}$.

The presence of fecal coliform bacteria in water is an indicator that the water has been contaminated with sewage and other possible pathogenic organisms. The results of this study indicate that river water contains fecal coliform bacteria exceeding the water quality criteria.

Table 4. Mean water quality parameters values of rivers and lakes of Huasteca Potosina.

\begin{tabular}{lccccccc}
\hline & $\begin{array}{c}\text { WHO } \\
{[13]}\end{array}$ & S1 & S2 & S3 & S4 & S5 & S6 \\
\hline T & & 29.8 & 29.5 & 29.5 & 28.9 & 31.5 & 30.4 \\
$\mathbf{p H}$ & $6.5-8.5$ & 8.2 & 7.9 & 7.9 & 8.4 & 8.8 & 8.7 \\
TS & 1000 & 396 & 154 & 208 & 838 & 624 & 631 \\
DO & & 6.0 & 7.7 & 6.0 & 4.8 & 10.5 & 4.7 \\
Sa\% & & 78.4 & 101.8 & 78.2 & 63.3 & 142.2 & 63.8 \\
Tur. & $<5$ & 16.0 & 2.5 & 4.7 & 5.0 & 2.6 & 5.8 \\
PO $_{4}$ & & 0.2 & 0.3 & 0.2 & 8.9 & 5.9 & 8.3 \\
NO $_{3}$ & 50 & 5.8 & 2.7 & 0.7 & 21.7 & 13.7 & 19.6 \\
BOD $^{5}$ & & 4.2 & 0.0 & 5.8 & 4.9 & 5.0 & 8.0 \\
FC & & 240.0 & 0.0 & 4.0 & 43.0 & 4.0 & 93.0 \\
\hline
\end{tabular}




\begin{tabular}{lccccccc}
\hline & $\begin{array}{c}\text { WHO } \\
{[13]}\end{array}$ & S7 & S8 & S9 & S10 & S11 & S12 \\
\hline T & & 34.9 & 29.0 & 33.4 & 32.8 & 31.6 & 25.6 \\
pH & $6.5-8.5$ & 8.5 & 7.9 & 8.2 & 8.7 & 7.9 & 7.6 \\
TS & 1000 & 552 & 914 & 2006 & 838 & 764 & 1600 \\
DO & & 6.8 & 4.8 & 4.8 & 8.6 & 4.9 & 5.0 \\
Sa\% & & 95.9 & 62.4 & 66.8 & 119.7 & 67.1 & 61.6 \\
Tur. & $<5$ & 190.0 & 4.9 & 62.1 & 4.3 & 2.8 & 0.2 \\
PO $_{4}$ & & 1.0 & 1.5 & 0.7 & 3.7 & 0.6 & 0.5 \\
NO $_{3}$ & 50 & 11.0 & 1.0 & 10.3 & 10.3 & 0.3 & 2.3 \\
BOD & & 5.8 & 5.0 & 6.4 & 6.5 & 2.8 & 5.8 \\
FC & & 460 & 93 & 240 & 150 & 75 & 15 \\
\hline
\end{tabular}

\subsection{Application of NSF-WQI}

Considering the application of NSF-WQI, the water quality in the river is at a medium level based on the categories in Table 3, as presented in Table 5 below. The Tancuilin and Axtla rivers located in the municipalities of Matlapa and Axtla de Terrazas, respectively, obtained good quality with an NSF-WQI score of 90 and 82, respectively. In contrast, the Moctezuma River in the municipality of Tanquian de Escobedo obtained an NFS score of 50, placing the river with low water quality. Water bodies such as the Amajac River, Montezuma river, Patitos lagoon, Tampaón river, Plan de Iguala lagoon, Panuco river, Valles river, and Puente de Dios river were placed in the medium category, with the NFSWQI value range of 55-68.

Table 5. NSF-WQI values of rivers and lakes of Huasteca Potosina

\begin{tabular}{ccc}
\multicolumn{3}{c}{ of Huasteca Potosina } \\
\hline Place & NSF-WQI value & Class \\
\hline S1 & 67 & Medium \\
S2 & 90 & Good \\
S3 & 82 & Good \\
S4 & 55 & Medium \\
S5 & 57 & Medium \\
S6 & 50 & Bad \\
S7 & 53 & Medium \\
S8 & 63 & Medium \\
S9 & 54 & Medium \\
S10 & 56 & Medium \\
S11 & 67 & Medium \\
S12 & 68 & Medium \\
\hline
\end{tabular}

\section{Conclusion}

This study demonstrates the advantages of using WQI in assessing overall water quality and summarizing large amounts of data into a single value. The water from the rivers and lagoons of the Huasteca Potosina can be consumed by the community after traditional treatment; however, the results show that anthropogenic activities contaminate the rivers and lagoons, and the NFS WQI values were 50-90, which indicates a medium and good water quality in the case of the Tancuilin and Axtla rivers. The use of WQI is more systematic and provides a comparative assessment of water quality from the sampling stations. It is likewise beneficial for community to recognize water quality and be a beneficial device in water quality management.

\section{References}

1. Instituto Nacional de Estadística y Geografía (INEGI). Anuario estadístico y geográfico de San Luis Potosí 2017. Available in: www.inegi.org.mx (2017)

2. Instituto Nacional de Estadística y Geografía (INEGI), \& Cadena, A. Hidrología. In Síntesis Geográfica del Estado de San Luis Potosí (p. 4). Instituto Nacional de Estadística y Geografía. (1985)

3. Ball, R. Church, R. Water Quality Indexing And Scoring.Journal of The Environmental Engineering Division, American Society Of Civil Engineers, 106, EE4, 757-771. (1980)

4. Hussein Ewaid, S. Water quality evaluation of AlGharraf river by two water quality indices. Applied Water Science, 7(7), 3759-3765. https://doi.org/10.1007/s13201-016-0523-z (2017)

5. Fernandez, N. J., \& Solano, F. Capítulo III: índices de calidad (ICAs) y de contaminación (ICOs) del agua de importancia mundial. In Índices De Calidad Y De Contaminación Del Agua (pp. 43113). Universidad de Pamplona (2007)

6. Ott, W. Environmental Indices, Theory And Practice, AA Science, Ann Arbor, Michigan. (1978)

7. Brown R., Mcclelland N., Deininger R., Tozer R. "A Water Quality Index- Do We Dare?" Water And Sewage Works. October. P. 339-343 (1970)

8. Abbasi T, Abbasi SA Water quality indices. Elsevier, Amsterdam, p 384 (2012)

9. American Public Health Association (APHA) Standard methods for the examination of water and wastewater, 27th edn. Washington, DC (2012)

10. [NSF] National Sanitation Foundation International. The Public Health and Safety Organization. Avaiable in: https://www.nsf.org/ (Accessed on september of 2020).

11. Rai RK, Upadhyay A, Ojha CSP, Singh VP. The Yamuna River basin. Water Science and Technology Library 66:307-356 (2012)

12. USGS National field manual for the collection of water quality data, techniques of water resources, book 9, handbooks for water resources investigations, pp 1539 (2015)

13. World Health Organization (WHO) Guidelines for drinking water quality, 4th edn. Available in: http://www.who.int/water. Accessed August 2020 (2011)

14. Simon FX, Penru Y, Guastalli AR, Lorens J, Baig S. Improvement of the analysis of the biochemical oxygen demand (BOD) of Mediterranean seawater by seeding control. Talanta 85(1):527-532 (2011)

15. Fulazzaky MA.Water quality evaluation system to assess the status and the suitability of the Citarum 
river water to different uses. Env Monit Assess 168(1-4):669-684 (2010)

16. Naubi I, Zardari NH, Shirazi SM, Ibrahim NFB, Baloo L. Effectiveness of water quality index for monitoring Malaysian river water quality. Pol J Environ Stud 25(1):231-239 (2016)

17. CONAGUA, Statistics of Water in Mexico. Edition 2013. México. 2014.

18. Ell MJ. Total suspended solids (TSS). In: NDDO Health (ed), North Dakota, USA (2008)

19. Viessman W, Hammer MJ. Water supply and pollution control, 7th edn. The University of Michigan, Pearson Prentice Hall, USA (2005) 